Thomas Blake Earle \& D. Andrew Johnson (eds.), Atlantic Environments of the American South. Athens: University of Georgia Press, 2020. xxii + 226 pp. (Paper US\$29.95)

This collection of essays emerged from a 2016 symposium at Rice University aimed at seeking a new framework for understanding the histories of slavery and empire grounded in an expansive American South. The editors have drawn skillfully on a variety of historiographic traditions, from Fernand Braudel's Annales school to borderlands history, among others. They convincingly locate a new field of study at the intersections and refractions of Atlantic, environmental, and Southern history.

The book's four sections create space for new questions and deeper understandings about the relationships between historical actors, the environment, and the structures of governance and exploitation within a capacious American South. In Part One, "Slavery and Climate," Sean Morey Smith and Elaine LaFay confront competing experiences and evolving theories of the region's pervasive heat and humidity. Morey Smith finds that in the late seventeenth century, boosters promoted Carolina as more "salubrious" than Caribbean colonies. But the development of the rice-based plantation economy, which provided a plentiful habitat for mosquitos, altered White settler-colonialists' perceptions of the region's climate as less temperate than before, its inhabitants now more prone to malaria. LaFay argues that enslavers' principles of scientific management and "theories of race science" animated promotion of well-ventilated cabins for enslaved laborers (p. 38). However, "well-ventilated" in theory translated to drafty and poorly constructed in practice, and enslaved people pushed back by adjusting their living spaces according to their own preferences.

In Part Two, "Slavery and Landscape," Matthew Mulcahy and Hayley Negrin explore the landscapes envisioned, produced, and contested by settler-colonialists, enslaved workers, and Indigenous peoples in the wake of European imperialism and the transatlantic slave trade. Mulcahy's incisive essay points to the slow disaster of drought. Cash-crop monoculture dominated many Caribbean islands, as profit-hungry enslavers refused to yield acreage to subsistence agriculture, so in times of drought and imperial conflict, which cut off trade routes, enslaved workers died by the tens of thousands from this engineered deprivation. Negrin traces the gendered "legal chain of reasoning" by which White colonists from Carolina to Virginia legitimated seizure of Indigenous land, the co-option of Indigenous women's agricultural practices, and the enslavement of Indigenous peoples. 
Part Three, "Empire and Infrastructure," opens the half of the volume focused on empire. Bradford J. Wood reveals the instability of empire within the "ulterior Atlantic," specifically colonial North Carolina (p. 115). The colony's coast, guarded by islands, sand bars, and stormy waters, posed a dangerous barrier to the colony's full integration into transatlantic trade routes and the plantation economy. Frances Kolb wanders up the Lower Mississippi Valley to situate a provocative argument that "commerce bypass[ed] imperial oversight and control" in the region after the Seven Years' War (p. 146). There, British merchants, Indigenous polities, and colonists in Spanish Louisiana produced new alliances and strengthened older trade networks to "transform ... an intricate chain of waterways into a strong commercial connection to the Atlantic World," with consequences that would reverberate for generations after.

Part Four, "Empire and Expertise," explores the production of expertise and environmental knowledge. Melissa N. Morris provides a fascinating look at the "intellectual transfers that necessarily accompanied botanical exchanges" between the English and the Spanish in pursuit of tobacco as a cash crop, while never ignoring "the Native American and African peoples they exploited in the process" (p. 158). Keith Pluymers also examines the complexities of competition and exchange between English and Spanish imperial agents, albeit in early seventeenth-century Bermuda. There, English colonists hoped to emulate what they saw as the flourishing of Spanish-occupied Caribbean islands, but routinely failed to retain colonists. To counterbalance the environmental and economic fluctuations that troubled their dreams for success, they developed ever stricter means of controlling enslaved African labor. Finally, Peter C. Messer analyzes William Bartram's famous 1791 travelogue, suggesting that Bartram posited a "more contemplative and philosophical vision of natural history" that defied European-settler presuppositions of "taxonomical science and aesthetics" (pp. 197, 201).

Alejandra Dubcovsky provides a brief, incisive conclusion, pointing out that the collection "balances big questions with local examples" (p. 218). That observation frames this book's most noteworthy contribution; its broadly writ American South, while sometimes unwieldy in its span from the Caribbean to the Mississippi and perhaps surprisingly empty of discussions of the nascent development of racial capitalism, forces readers out of the teleology of U.S. history and reveals the contingency of the American South and its inextricable Atlantic connections in the seventeenth and eighteenth centuries. The essays use granular attention to the impacts of settler-colonialism, human-produced landscapes, and dynamic, unpredictable environments to further our scholarly understanding that empire and slavery were not monolithic processes imposed on a homogenous space. Indeed, the watery and terrestrial environments of 
the Atlantic world in the early modern era require historical analysis, and this collection demonstrates how that attention can produce rich and meaningful scholarship.

\section{Caroline Grego}

Department of History, Queens University, Charlotte NC, U.S.A.

gregoc@queens.edu 